Print ISSN: 2671-4981 / Online ISSN: 2671-499X

doi:10.13106/jbees.2019.vol9.no4.29

\title{
Current Situation of Cryptocurrency in Vietnam
}

\author{
Thu Thuy DANG*
}

Received: September 06, 2019. Revised: July 29. Accepted: October 05. 2019.

\begin{abstract}
Purpose - The purpose of the research is to assess the current state of cryptocurrency in Vietnam and to provide several solutions and recommendations to the Government, the State Bank of Vietnam (SBV) and other relevant agencies for monitoring, managing, and controlling cryptocurrency effectively and efficiently.

Research design, data and methodology - The study is based on the assessment and analysis of cryptocurrency in the world and the real situation of cryptocurrency in Vietnam in order to provide solutions to the controllable development of operation of this currency.

Results - The study indicates the current operations of cryptocurrency in Vietnam and provides several suggestions to effectively control this currency.

Conclusion - According to the study on current cryptocurrency and the situation of cryptocurrency in Vietnam, the author has proposed a number of solutions to provide suggestions to manage and develop the operations of cryptocurrency in a most practical manner. The governments of many countries in the world, including the Government of Vietnam, need more time as well as appropriate technology improvements to take advantage of these new digital currencies; therefore, they still need to ensure safety in compliance with the control and regulatory capabilities of the central government and central banks.
\end{abstract}

Keywords: Cryptocurrency, Vietnam.

JEL Classifications: G0, G10, G23.

\section{Introduction}

In the world, Bitcoin has been classified into the currency group named Cryptocurrency. In Vietnam, the translation of the above terminology into Vietnamese is still not available. In terms of technology, Cryptocurrency is often translated as encrypted currency because crypto is the short name for cryptography. Accordingly, Cryptocurrency is a cryptographic protocol used to transfer data. Regarding the economic perspective, Cryptocurrency is often translated and should be translated as digital money. However, this translation is easily confused with digital currency. When

\footnotetext{
1 Ph.D Vietnam Institute for Indian and Southwest Asian Studies \& Vietnam Academy of Social Sciences (VASS), Vietnam.

Tel: +84-90-921-1080, Email: thuy0183@gmail.com

(๑) Copyright: Korean Distribution Science Association (KODISA)

This is an Open Access article distributed under the terms of the Creative Commons Attribution NonCommercial License (https://creativecommons.org/licenses/by-nc/4.0/) which permits unrestricted noncommercial use, distribution, and reproduction in any medium, provided the original work is properly cited.
}

referring to Bitcoin, many people mistake Bitcoin as virtual currency. However, virtual currency has its own term, virtual currency, which is completely different from Cryptocurrency. The confusion in the use of such terms as cryptocurrency, electronic currency and virtual currency is due to the relatively small delimitation among them. In particular, the distinction between electronic currency and virtual currency is evident by criteria in terms of issuer, scope of acceptability, value reserve function... However, it is quite difficult to differentiate among cryptocurrency, virtual currency, and electronic currency because cryptocurrency is put in the "intersection" between the two remaining kinds of currencies. More specifically, cryptocurrency is virtual currency in nature but it is increasingly like digital currency (see Figure 1). 


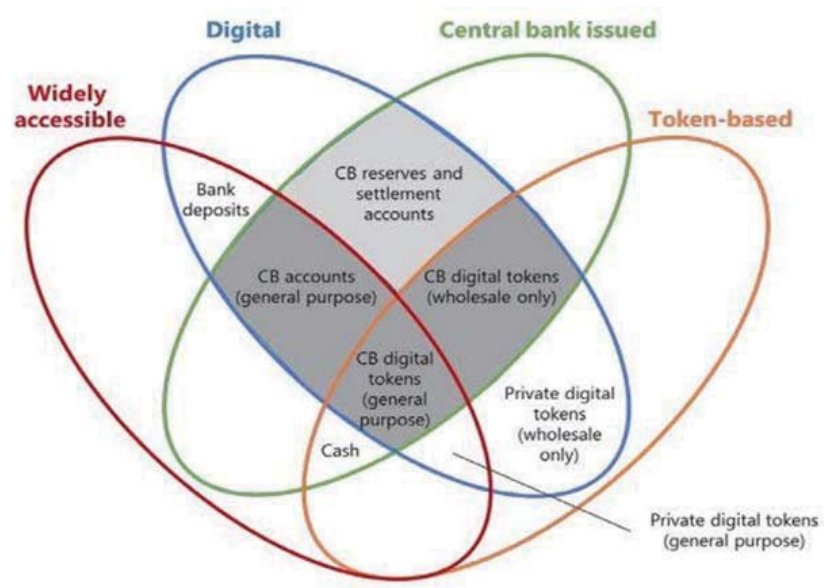

Source: Morten Linnemann Bech and Rodney Garratt (2017)

Figure 1: Classification of Currencies

\section{Distinguish the Concepts of Electronic Currency, Virtual Currency, and Cryptocurrency}

According to the European Central Bank (ECB) ${ }^{1}$, "electronic money (e-money) is broadly defined as an electronic store of monetary value on a technical device that may be widely used for making payments to entities other than the e-money issuer". Lanskoy (2000) suggests, "Electronic currency is stored in a special device, usually on the hard drive of your PC or a microprocessor card, and that can be transmitted from one device to another using telecommunication lines and other electronic media". Therefore, electronic currency is embedded with the following characteristics: (i) stored value by electronic means; (ii) represented by the right of recourse against an electronic currency issuer; (iii) issued on a cash basis; (iv) used to make payment transactions; and ( $v$ ) accepted by a legal persons or entity that is not an electronic currency issuer.

A world common definition of virtual currency by the ECB (2012) is as follows "electronic money issued and usually controlled by its developers and used and accepted among the members of a specific virtual community". The term virtual currency has undergone quite some changes in 2013 and 2014. Financial Crimes Enforcement Network classified virtual currency as "a medium of exchange operating like a currency in some environments but without having all of the true attributes of a currency." Therefore, these are value

\footnotetext{
1 https://www.ecb.europa.eu/stats/money_credit_banking/ electronic_money/html/index.en.html
}

storage instruments in an electronic way: (i) not issued by a bank or another public organization, without any relation to a certain amount of currency; (ii) accepted by a public part in payment, transfer, storage or transaction via electronic channels. For example, virtual currency is Pokecoins in Pokemon GO game or Facebook credit amounts used for advertising or games on the Facebook app...

As mentioned above, the cryptocurrency lies in the intersection between digital currency and virtual currency. This currency is originally convertible virtual currency but it is increasingly growing and similar to electronic currency. Accordingly, cryptocurrency has the characteristics of digital currency and virtual currency (see Table 1).

Table 1: Comparison of Electronic Currency, Virtual Currency and Cryptocurrency

\begin{tabular}{|c|c|c|c|}
\hline Characteristics & $\begin{array}{l}\text { Electronic } \\
\text { currency }\end{array}$ & $\begin{array}{c}\text { Virtual } \\
\text { currency }\end{array}$ & Cryptocurrency \\
\hline $\begin{array}{l}\text { Associated with } \\
\text { the right of } \\
\text { collection, there } \\
\text { is intrinsic value }\end{array}$ & Yes & No & $\begin{array}{l}\text { No (unless the } \\
\text { issuer is a } \\
\text { central bank) }\end{array}$ \\
\hline $\begin{array}{l}\text { The ability to } \\
\text { convert } \\
\text { currency into } \\
\text { real currency }\end{array}$ & Yes & $\begin{array}{c}\text { Little, regarding } \\
\text { conditions, } \\
\text { extremely } \\
\text { limited scope } \\
\end{array}$ & Yes \\
\hline $\begin{array}{c}\text { The } \\
\text { management of } \\
\text { the central } \\
\text { bank/national } \\
\text { government }\end{array}$ & Yes & No & $\begin{array}{l}\text { No (unless the } \\
\text { issuer is a } \\
\text { central bank) }\end{array}$ \\
\hline $\begin{array}{c}\text { Transaction } \\
\text { characteristics }\end{array}$ & Centralized & Decentralized & Centralized \\
\hline $\begin{array}{c}\text { As a payment } \\
\text { instrument }\end{array}$ & $\begin{array}{l}\text { Yes, the wide } \\
\text { range (thanks } \\
\text { to the issuer's } \\
\text { reputation) }\end{array}$ & $\begin{array}{l}\text { Limited to the } \\
\text { scope of } 1 \\
\text { company or } 1 \\
\text { small group of } \\
\text { companies } \\
\end{array}$ & $\begin{array}{c}\text { Yes, the wide } \\
\text { range (thanks to } \\
\text { the development } \\
\text { of secondary } \\
\text { transactions) }\end{array}$ \\
\hline $\begin{array}{l}\text { The level of } \\
\text { safety and } \\
\text { public trust }\end{array}$ & $\begin{array}{c}\text { High (thanks to } \\
\text { the issuer) }\end{array}$ & Low & $\begin{array}{l}\text { High (thanks to } \\
\text { Blockchain } \\
\text { technology) }\end{array}$ \\
\hline $\begin{array}{c}\text { Transaction } \\
\text { costs }\end{array}$ & High & Low & Very low \\
\hline $\begin{array}{l}\text { Approach } \\
\text { capability }\end{array}$ & Global scope & $\begin{array}{c}\text { Certain } \\
\text { communities }\end{array}$ & Global scope \\
\hline Storage form & Physical & Electronic & Electronic \\
\hline Risk fluctuation & Low & Unidentified & High \\
\hline
\end{tabular}

Source: ECB (2015), ECB (2017), BIS (2017)

\section{Cryptocurrency}

\subsection{Blockchain and the Birth of Bitcoin}

Since it was founded in 2009, Bitcoin has become the first digital currency able to solve the double spending problem based on Blockchain technology. Anyone who understands programming can join in "Bitcoin mining" by using a 
computer system to solve increasingly complex algorithms. Currently, 12.5 Bitcoins are issued every 12 minutes. To date, the number of issued Bitcoins has been 11 million; it will reach a maximum of 21 million by the year 2140 . In fact, there is no "Bitcoin" in the physical form, those owning a few Bitcoins means they own some encryption keys stored on a computer, external hard disk, or printed on paper. These encryption keys will allow the holders to use the same Bitcoin balance as using the balance on online bank accounts. The difference is that the owners can't withdraw Bitcoin out of the network like withdrawal from the bank.

Characteristics of Blockchain technology include (i) a joint owning ledger, without a proprietary server, unchanged over time; therefore, ensuring transparency, security, fraud prevention and free of charge; (ii) decentralized management with sharing in the process; thus, enabling real-time performance with fast processing speed and low cost.

\subsection{Bitcoin Evolution}

When created in 2009, Bitcoin had a very low value (about 0.35 USD). Along with the development of the Bitcoin community, the value of this currency has increased gradually. In April 2011, the price of US\$ 1 was seen as the start of the first Bitcoin bubble. In June 2011, Bitcoin was priced at more than $\$ 30$, and then quickly dropped to $\$ 2$ at the end of 2011. This loop took place twice in 2013. In May 2013 , Bitcoin was priced at over $\$ 250$ but then decreased to about $80 \%$ of its price. At the end of 2013 , the Bitcoin price exceeded $\$ 1,000$, but lost $80 \%$ of price for the second times. In early 2015 , the Bitcoin price was only $\$ 200$, but in December 2017 it was over $\$ 18,000$. Currently, the market has cooled down to about $\$ 8,000$ /Bitcoin. Bitcoin price is rising as more and more people believe that the uptrend will continue in the future while the supply is limited (limited to 21 million units), causing the supply-demand relationship gaps.

In terms of potential, Blockchain technology has never existed before; therefore, it takes time to test Blockchain, with its representative being Bitcoin which has many important applications, suggesting new directions of "shared economy". For example, money transfer or payment using this technology (via Bitcoin, Ripple ...) is low cost and kept unchanged with any value. However, implementing this technology at a large scale requires relatively long time to (i) build the necessary infrastructure and (ii) persuading entities in the economy to use.

Currently, many contradictory opinions on the development prospects of Bitcoin have been raised. Optimists predict that Bitcoin is becoming a reserve currency for a broader virtual economy (similar to the role of the dollar in the real economy). The development of the above economy will contribute to make Bitcoin have higher prices and be more widely accepted. In contrast, some argue that, due to features such as risk (to be analyzed below) and limited numbers, Bitcoin will continue to be banned by many countries, and it may disappear on its own in a few coming decades.

\subsection{The Current Cryptocurrency System}

As of January 1, 2018, the Internet recorded the appearance of 1,508 different types of cryptocurrency with a total capitalization of $\$ 519.6$ billion. Bitcoin is the first and most popular cryptocurrency, with a current market capitalization of $\$ 187$ billion (33.1\% of market share). It is followed by Ethereum, developed in 2015, with a market capitalization of about $\$ 112$ billion ( $21 \%$ of market share). It is also a kind of currency having significant price increase from about $\$ 400$ in 2015 to $\$ 1,153$ today. Ripple coin is ranked at the third level with a market capitalization of $\$ 49$ billion ( $8 \%$ of market share). This currency is promising to make a big difference in currency transfer, which can replace the international currency transfer network SWIFT due to its cost saving, flexibility in liquidity and high compatibility. The currency is being used by Mitsubishi for fast, cost-effective transfer and superior to PayPal. Although not ranked in the top 3 but Litecoin, with capitalization of about $\$ 9.8$ billion $(1.7 \%$ of market share), is of great interest due to some of the outstanding features such as faster payment and process allowing more transactions (see Table 2).

Table 2: Bitcoin and Three Popular Cryptocurrency as of January 2018

\begin{tabular}{|c|c|c|c|c|}
\hline Characteristics & Bitcoin & Litecoin & Ethereum & Ripple \\
\hline Use & $\begin{array}{c}\text { Peer } \\
\text { payment }\end{array}$ & $\begin{array}{c}\text { Peer } \\
\text { payment }\end{array}$ & $\begin{array}{c}\text { Smart } \\
\text { contracts on } \\
\text { mobile } \\
\text { devices }\end{array}$ & $\begin{array}{c}\text { Transactions } \\
\text { between } \\
\text { banks }\end{array}$ \\
\hline $\begin{array}{c}\text { Yield (compared } \\
\text { to the same } \\
\text { period last year) }\end{array}$ & $1,500 \%$ & $6,000 \%$ & $7,500 \%$ & $30,000 \%$ \\
\hline Total supply & 21 million & 84 million & Unlimited & 100 billion \\
\hline $\begin{array}{c}\text { Public } \\
\text { identification }\end{array}$ & High & Low & High & Low \\
\hline Community use & Very big & Big & Very big & Small \\
\hline
\end{tabular}

Source: Nguồn, https://coinmarketcap.com/

Every country in the world has different approaches to this new currency. If the Netherlands accepts it recklessly, the United Kingdom and the US are more cautious with this currency because of their fear for speculation, and potential risks to the economy. In contrast, China, and Thailand tend to adopt increasingly tightening and prudent policies on this kind of currency (see Table 3). 
Table 3: Countries Have Access to Cryptocurrency

\begin{tabular}{|c|c|c|c|}
\hline Countries & Policy & Regulation on cryptocurrency & Point of view of central banks or the leaders \\
\hline Netherlands & $\begin{array}{l}\text { Accept } \\
\text { recklessly }\end{array}$ & $\begin{array}{l}\text { + Be a leading pioneering country. } \\
\text { In } 2015 \text {, a bold experiment with the release of DNB } \\
\text { coin was experimented for use in the country to } \\
\text { research the cryptocurrency. }\end{array}$ & $\begin{array}{l}+ \text { In } 2016 \text {, the DNBcoin project leader stated that } \\
\text { Blockchain can be easily applied in complex } \\
\text { financial transaction settlement systems. }\end{array}$ \\
\hline England & $\begin{array}{l}\text { Accept } \\
\text { cautiously }\end{array}$ & $\begin{array}{l}+ \text { In August 2015, Barclays-the first major bank } \\
\text { accepted Bitcoin. }\end{array}$ & $\begin{array}{l}+ \text { The Central Bank Governor said the } \\
\text { cryptocurrency was part of a "future revolution" in } \\
\text { the financial sector. Accordingly, banks learn anti- } \\
\text { hacking skills and improve payment operations. } \\
\text { However, he also emphasized the central bank's } \\
\text { decision on issuance of cryptocurrency was still } \\
\text { impossible. }\end{array}$ \\
\hline America & $\begin{array}{l}\text { Accept } \\
\text { cautiously }\end{array}$ & $\begin{array}{l}\text { Recognized in each separate state. } \\
+ \text { In September 2016, the Future Commodity } \\
\text { Trading Commission determined that Bitcoin was a } \\
\text { commodity such as gold or oil. } \\
+ \text { In July } 2017 \text {, the Securities and Exchange } \\
\text { Commission (SEC) said it was possible to apply } \\
\text { federal securities laws to cryptocurrency } \\
\text { transactions. }\end{array}$ & $\begin{array}{l}\text { The FED President called Bitcoin "a highly } \\
\text { speculative asset" and raised the question of: (i) } \\
\text { responding appropriately to the emergence and } \\
\text { development of digital currency issued by private } \\
\text { entities; (ii) should officially recognized digital } \\
\text { currency be issued? }\end{array}$ \\
\hline Thailand & $\begin{array}{l}\text { Ban, } \\
\text { gradually } \\
\text { loosen } \\
\text { regulation }\end{array}$ & $\begin{array}{l}+ \text { In July } 2013 \text {, the central bank determined that } \\
\text { Bitcoin was not a currency unit and Thailand was } \\
\text { the first country in the world to ban circulation. }\end{array}$ & $\begin{array}{l}+ \text { In February 2014, the Ministry of Finance } \\
\text { declared that the central bank had no authority } \\
\text { over Bitcoin, allowing Thailand Bitcoin company to } \\
\text { register its business. }\end{array}$ \\
\hline China & Ban toughly & $\begin{array}{l}\text { + In December } 2013 \text {, the central bank banned the } \\
\text { country's financial institutions from trading Bitcoin } \\
\text { and trading websites had to provide investors' } \\
\text { identity for management. } \\
+ \text { In February/2017, the central bank checked nine } \\
\text { Bitcoins and it finished such checking in September } \\
2017 \text {. Accordingly, it does not recognize the } \\
\text { legitimacy of the ICO and request stop } \\
\text { immediately. }\end{array}$ & $\begin{array}{l}\text { + In } 2014 \text {, the central bank established a research } \\
\text { team on cryptocurrency and applications in } \\
\text { collaboration with Citigroup and Deloitte. } \\
+ \text { At the end of } 2017 \text {, the central bank said it had } \\
\text { fully controlled the cryptocurrency on the basis of a } \\
\text { strong grasp of technology and prohibited the } \\
\text { exchange of digital currency. }\end{array}$ \\
\hline
\end{tabular}

Source: Bloomberg

\section{Current Situation of Circulation, Use, and Management of Cryptocurrency in Vietnam}

Bitcoin first appeared in Vietnam at the end of 2013 and at the beginning of 2014 in two major centers, including Hanoi and Ho Chi Minh City. At present, Vietnam as well as many countries are still embarrassed about behaving with the cryptocurrency and related activities (exchanging transactions, importing and using digital currency "digging" machine...). In Vietnam, Bitcoin has been traded but not recognized by the Government as a currency or means of payment, and it has not been managed and put under control. The informal cryptocurrency transfer activities have been developed relatively, even spreading in rural areas, accompanied by fraudulent activities and lack of transparency. In March, 2014, in Vietnam, the first Bitcoin dealer named Bitcoin Vietnam was set up at Bitcoin.vn, forming the Bitcoin VBTC Exchange. On June $5^{\text {th }}$ 2016, the first Bitcoin ATM machine existed in Vietnam. In 2 years of 2016-2017, nearly 1000 Bitcoin diggers were imported to Vietnam.

On August $21^{\text {st }} 2017$, the Prime Minister approved the project of improving the legal framework for management of virtual assets, electronic currency, digital currency, including Bitcoin. Over the past time, the SBV has repeatedly issued warnings, affirming that Vietnam has not accepted cryptocurrency as monetary currency; the use of cryptocurrency as payment means violates the law. Previously, the State Bank of Vietnam (SBV) submitted the Government to issue Decree 80/2016/ND-CP providing regulation on legal means of payment in Vietnam (excluding Bitcoin and other cryptocurrency) and additional regulations on prohibiting issuance, supply, and use of cryptocurrency. 
Decree 96/2014/ND-CP stipulated sanctions on administrative fines to illegal issuance, provision and use of payment instruments. In essence, the SBV believes that cryptocurrency is virtual assets (often called coins). However, both the Civil Code of 2005 and the Civil Code of 2015 have not yet had definitions and specific regulations on governing virtual properties (including cryptocurrency).

\section{Proposed Solutions to Manage Digital Currency in Vietnam}

Cryptocurrency can be considered the humankind invention, it will continue to exist; therefore, it cannot be completely prevented but it should be controlled and managed in a prudent manner. Accordingly, the Government should have appropriate management measures. Acceptance of the cryptocurrency at this stage may not be appropriate in practice in Vietnam. However, it cannot go against the trend, and the practical requirement of absolute ban on using this currency. Accordingly, it is possible to manage Bitcoin as well as other cryptocurrency as "virtual assets". Specifically:

(i) According to the international experience in electronic currency management, it can be said that the management of cryptocurrency in Vietnam needs to be tightened. Organizations and individuals participating in providing services related to digital currency must be licensed according to certain standards. The activities of these organizations and individuals should be regularly monitored, ensuring transparency. In addition, there should be regulations to ensure safety in the operation of organizations involved in providing services related to cryptocurrency such as regulations on the separation of assets between assets of customers and assets of companies; separate accounts must be opened at the Credit Institutions (Cls).

(ii) For individuals and organizations "digging" or exploiting Bitcoin: the value of Bitcoin can be regarded as income; therefore, the income tax on the income earned from "digging" Bitcoin.

(iii) Cryptocurrency (including Bitcoin) should not be regarded as currencies, but they may be considered to be speculative financial products. Accordingly, there should be effective licensing, reporting, monitoring and supervision mechanisms.

(iv) Blockchain technology platform is a trend and will be widely applied due to many advantages of this technology. Therefore, it is necessary to learn early, approach and create legal corridors so that organizations and enterprises of Vietnam can deploy and control the risks of this Blockchain technology platform. (v) Policies should be put in place to improve the quality of IT infrastructure provide training for the management team, financial experts, IT experts...to take advantage of opportunities and control risks from these new financial technological products.

(vi) Promote propaganda, communication and warn citizens and investors against the risks of digital currency system simultaneously develop and implement the financial education strategy as an important component of the national strategy on comprehensive finance.

\section{Conclusions}

In the current Industrial Revolution Era 4.0, the emergence and development of algorithmic currency morphology is indispensable. However, the governments of many countries in the world, including the Government of Vietnam, need more time as well as appropriate technology improvements to take advantage of these new digital currencies; therefore, they still need to ensure safety in compliance with the control and regulatory capabilities of the central government and central banks.

\section{References}

Ali, R., Barrdear, J., Clews, R., \& Southgate, J. (2014). Innovations inpayment technologies and the emergence of digital currencies. Bank of England Quarterly Bulletin, 54(3), 262-275.

Bech, M. L., \& Garratt, K. (2017, September). Central Bank Cryptocurrencies. BIS Quarterly Review, Retrieved May 11, 2019, from https://www.bis.org/publ/qtrpdf/r_qt1709f.htm

Bollen, R. (2013). The Legal Status of Online Currencies: Are Bitcoins the Future? Journal of Banking and Finance Law and Practice, 24(3), 272-93.

European Central Bank (ECB) (2012). Virtual Currency Schemes.

ECB(2015). Virtual currency schemes - A further analysis.

ECB (2017). Impact of digital innovation on the processing of electronic payments and contracting: An overview of legal risks (Legal Working Paper Series).

Geva, B. (2016). Virtual Currencies and Block Chains: Developments and Issues. National Banking Law Review, 35(3), 36-42.

Kalderon, M., Snagg, F., \& Harrop, C. (2016). Distributed Ledgers: A future in Financial Services? Journal of International Banking Law and Regulation, 31(5), 243247. 
Lanskoy, S. (2000). The Legal Nature of electronic money (Bangue de France Bulletin Digest-No73)

Quest, D. Q. C. (2015). Taking Security over bitcoins and other virtual currency. Butterworths Journal of International Banking and Financial Law, Retrieved May 11, 2019, from https://www.financialinstitutionslegalsnapshot.com/

Rosner, M. T., \& Kang, A. (2016). Understanding and Regulating Twenty-First Century Payment Systems: The Ripple Case Study. Michigan Law Review, 114(4), 649681.

Perkins, J., \& Enwezor, J. (2016). The legal aspects of virtual currencies. Butterworths Journal of International
Banking and Financial Law, Retrieved May 11, 2019, from http://fmlc.org/wp-content/uploads/2018/03/jibfl_2016_ vol31_issue10_nov_virtualcurrencies.pdf

Sams, R. (2015). Bitcoin Blockchain for Distributed Clearing: A Critical Assessment. The Capco Institute Journal of Financial Transformation Retrieved May 11, 2019, from https://www.securities-

services.societegenerale.com/fileadmin/user_upload/sgss lagenda/2016/5_42_Block_Chain_Critical_Assessment.p df

Wiseman, S. A. (2016). Property or Currency? The Tax Dilemma Behind Bitcoin. Utah Law Review, 2, 417-440 